\author{
Anna Cybulko \\ Uniwersytet Warszawski \\ (D) https://orcid.org/0000-0002-0875-8276 \\ https://doi.org/10.15633/9788374386753.01
}

\title{
Procesy poznawcze w komunikacji między stronami postępowania mediacyjnego
}

Konflikty są naturalną konsekwencją społecznej natury człowieka. Ludzie są różni, mają różne interesy i potrzeby, siłą rzeczy pojawiają się między nimi sprzeczności. Problemem, z którym warto się zmierzyć, są więc nie konflikty same w sobie, lecz awersyjny sposób ich prowadzenia, na który składa się w szczególności destrukcyjna komunikacja stron. Taką toksyczną i niszcząca komunikację obserwujemy często w konfliktach między osobami najbliższymi. W sporach rodzinnych, np. między małżonkami, rodzeństwem czy między rodzicami a dziećmi mamy do czynienia z relacjami o bardzo bliskim, intymnym wręcz charakterze, tematy będące przedmiotem sporu mają często kluczowe znaczenie dla funkcjonowania stron, a podnoszone kwestie mogą mocno dotykać poczucia tożsamości bądź samooceny. Specyfika sporów rodzinnych wiąże się też z tym, że są to na ogół relacje o trwałym charakterze, nie ulegające prostemu i szybkiemu rozwiązaniu na mocy decyzji stron. Nawet rozstający się małżonkowie, jeśli mają wspólne dzieci, jako rodzice pozostaną ze sobą związani do końca życia.

$\mathrm{W}$ radzeniu sobie $\mathrm{z}$ wyzwaniami komunikacyjnymi w sporach rodzinnych może pomóc włączenie do sporu mediatora: bezstronnej i neutralnej osoby trzeciej, która w sposób nieformalny, elastyczny i poufny pomaga stronom $\mathrm{w}$ samodzielnym dojściu do porozumienia. W rolę mediatora wpisane jest wspieranie i edukowanie stron w obszarze komunikacyjnym. Efektem mediacji może zatem być nie tylko osiągnięcie porozumienia co do różniących strony kwestii, ale także poprawa kompetencji komunikacyjnych stron, skutkująca lepszym porozumiewaniem się w przyszłości. Aby jednak mediator mógł sprawnie pomagać stronom, musi rozumieć, skąd biorą się obserwowane przez niego impasy, trudności czy blokady komunikacyjne. 
Barierą na drodze do rozwiązania konfliktu może być brak motywacji, kiedy jednej lub obu stronom nie zależy na tym, żeby zakończyć konflikt, brak kompetencji, np. umiejętności słuchania ze zrozumieniem czy radzenia sobie z własną impulsywnością, a także instrumentalne nastawienie do mediacji, wykorzystywanej dla własnych potrzeb, niezwiązanych z szukaniem rozwiązań istniejącego konfliktu. Bywa także, że do mediacji przystępują osoby, którym prawdziwie zależy na dojściu do porozumienia, mają podstawowe kompetencje komunikacyjne - wystarczające do codziennego komunikowania się ze światem i rozwiązywania stawianych przezeń problemów - jednak z jakichś względów nie są w stanie się ze sobą dogadać.

W niniejszym artykule postawiono tezę, że za istotną część trudności komunikacyjnych - szczególnie wyraźnie widocznych w konfliktach rodzinnych - odpowiadają mechanizmy psychologiczne rządzące ludzkim postrzeganiem. Systematyczne błędy poznawcze mogą utrudniać stronom adekwatny odbiór komunikatów nadawanych przez drugą stronę, co z kolei będzie skutkować trudnościami we wzajemnym zrozumieniu i niemożnością stworzenia wspólnej narracji. Rozumienie mechanizmów ludzkiej percepcji, umiejętność dostrzegania ich oddziaływania w danej sytuacji oraz świadomość tego, w jaki sposób mogą wpływać na eskalacje konfliktu, jest kluczową kompetencją mediatora. Zrozumienie podłoża psychologicznego pozwala na trafniejsze reagowanie na powstające trudności komunikacyjne i efektywniejsze wspieranie stron $\mathrm{w}$ dochodzeniu do porozumienia.

Punktem wyjścia prowadzonych rozważań będzie zdefiniowanie, czym jest komunikacja interpersonalna oraz omówienie modeli mediacji, ze szczególnym uwzględnieniem komunikacji jako tworzenia znaczenia. Przeanalizowane zostanie to, w jaki sposób strony w procesie porozumiewania się konstruują rzeczywistość. Następnie omówione zostanie, w jaki sposób wbudowane w ludzką psychikę mechanizmy poznawcze mogą generować nieporozumienia, utrudniać komunikację i wpływać na eskalację konfliktu. W podsumowaniu zdefiniowane zostaną zadania stojące $\mathrm{w}$ tym kontekście przed mediatorem oraz narzędzia, które mogą być pomocne w ich realizacji.

\section{Przyjęta koncepcja komunikacji}

Na potrzeby niniejszego tekstu komunikację interpersonalną będziemy rozumieć jako proces wymiany znaków i/lub symboli, które nabierają znaczenia 
w kontekście interakcji kilku osób. W komunikacji interpersonalnej biorą udział przynajmniej dwie osoby. Maksymalnym pułapem jest taka liczebność grupy komunikujących się, która pozwala wszystkim uczestnikom dostrzegać się wzajemnie i traktować w sposób podmiotowy ${ }^{1}$.

W teorii komunikacji wyróżnia się pewną liczbę modeli komunikacji, które podkreślają niektóre jej cechy i aspekty, ignorując inne. Wśród modeli wskazuje się np. model komunikacji jako: (1) transferu informacji, (2) uzgadniania znaczenia, (3) perswazji, (4) tworzenia społeczności². Inne ujęcie - bazujące na założeniu, że komunikacja to proces, w wyniku którego idee zawarte w jednym umyśle są przekazywane innym umysłom - wyróżnia następujące cztery paradygmaty:

- paradygmat kodowania - dekodowania, zakładający, że znaczenie jest właściwością komunikatu;

- paradygmat intencjonalny, zgodnie z którym zrozumienie składa się z rozpoznania intencji komunikacyjnych nadawcy;

- paradygmat przyjmowania różnych perspektyw, zakładający, że znaczenie ma źródło w punkcie widzenia adresata;

- paradygmat dialogu, koncentrujący się na zbiorowej naturze działania komunikacyjnego. $W$ tej perspektywie komunikacja postrzegana jest jako wspólne wypracowywanie znaczenia ${ }^{3}$.

Na potrzeby wyjaśniania zjawisk z zakresu komunikacji w konflikcie (analizowanej z perspektywy neutralnej osoby trzeciej) najbardziej użyteczne wydaje się przyjęcie perspektywy modelu komunikacji, w którym strony wspólnie uzgadniają znaczenie przekazywanych komunikatów. Podejście to wpisuje się zarówno w model komunikacji jako uzgadniania znaczenia, jak i w paradygmat dialogu. W obu tych ujęciach komunikacja zachodzi dwukierunkowo (od nadawcy do odbiorcy i od odbiorcy do nadawcy), a jej najważniejszym celem jest wzajemne zrozumienie uczestników komunikacji i osiągniecie zgody co do znaczenia wiadomości. Osią takiego myślenia o komunikacji jest założenie, że znaczenie nie jest wpisane w komunikat, lecz tworzy się w komunikacji między ludźmi, zgodnie z przekonaniem, iż

1 Por. S.P. Morreale, B.H. Spitzberg, J. K. Barge, Komunikacja między ludźmi. Motywacja, wiedza i umiejętności, Wydawnictwo Naukowe PWN, Warszawa 2007, s. 280.

2 Por. S.P. Morreale, B. H. Spitzberg, J. K. Barge, Komunikacja między ludźmi..., dz. cyt., s. 33.

3 Por. R. M. Krauss, E. Morsella, Konflikt a komunikacja, w: M. Deutsch, P. T. Coleman, Rozwiazywanie konfliktów. Teoria i praktyka, Wydawnictwo Uniwersytetu Jagiellońskiego, Kraków 2005, s. $132-140$. 
„Wiadomości, zarówno werbalne, jak niewerbalne, nie mają znaczenia same w sobie. Znaczenie nadają im ludzie, którzy je wyrażają i interpretują"4

Postrzeganie komunikacji jako uzgadniania znaczenia znajduje swoją podstawę teoretyczną m.in. w założeniach interakcjonizmu symbolicznego oraz społecznego konstruktywizmu. Zgodnie z założeniami koncepcji interakcjonizmu symbolicznego znaczenie jest produktem społecznej interakcji między ludźmi. Ludzie negocjują znaczenia, wykorzystując język (stąd termin symboliczny interakcjonizm). Interakcjoniści utrzymują, że zakres naszej wiedzy jest zależny od tego, co potrafimy nazwaćs. W tym ujęciu bezcelowe staje się poszukiwanie „prawdy” bądź „rzeczywistego znaczenia”. Prawdziwe jest to, co zostało za takie uznane. Jeśli ludzie zdefiniują jakąś sytuację jako rzeczywistą, staje się ona rzeczywista w swoich konsekwencjach ${ }^{6}$.

Społeczny konstruktywizm rozwija koncepcję zakładającą kluczową rolę języka w określaniu tego, kim jesteśmy i jak postrzegamy rzeczywistość. Dwa główne założenia hipotezy Sapira-Whorfa, leżącej u podstaw tej koncepcji, to determinizm językowy oraz relatywizm językowy. Zgodnie z założeniem determinizmu język kształtuje nasz sposób postrzegania świata, natomiast relatywizm zakłada, że różnice między systemami językowymi sprawiają, że ludzie myślący w różnych językach widzą świat odmiennie. Hipoteza Sapira-Whorfa przyjmuje różne postacie i daje podstawę wielu teoriom. Jednak najważniejsze z perspektywy prowadzonych rozważań jest przyjęcie, że przez organizowanie doświadczeń język w dużym stopniu wpływa na życie i konstruuje rozumienie świata i ludzi ${ }^{7}$. Ludzie inaczej zachowają się w sytuacji, którą nazwą konfliktem dotyczącym opieki nad dziećmi, a inaczej w sytuacji, którą określą jako potrzebę rozwiązania problemu opieki nad dziećmi. Należy się zgodzić ze stwierdzeniem Marii Lewickiej i Bogdana Wojciszke, iż: „Nasze postępowanie bardziej zależy od tego, jak swój świat rozumiemy, niż od tego, jaki ów świat w istocie jest. Ta sama sytuacja bywa różnie odczytywana przez różnych ludzi, a nawet przez tego samego człowieka przy różnych okazjach".

4 R. B. Adler, L. Rosenfeld, R. Proctor II, Relacje interpersonalne. Proces porozumiewania się, Dom Wydawniczy Rebis, Poznań 2011, s. 11.

5 Por. H. Blumer, Interakcjonizm symboliczny: perspektywa i metoda, Zakład Wydawniczy NOMOS, Kraków 2007.

6 Por. E. Griffin, Postawy komunikacji społecznej, Gdańskie Wydawnictwo Psychologiczne, Gdańsk 2003, s. 76-77.

7 Por. S.P. Morreale, B. H. Spitzberg, J. K. Barge, Komunikacja międzyludźmi..., dz. cyt., s. 147.

8 M. Lewicka, B. Wojciszke, Wiedza jednostki i sady o świecie społecznym, w: Psychologia. Podręcznik akademicki, t. 3, red. J. Strelau, Gdańskie Wydawnictwo Psychologiczne, Gdańsk 2005, s. 27. 
Z punktu widzenia prowadzonych rozważań istotną właściwością komunikacji jest to, że każda wiadomość ma zarówno wymiar treściowy, tj. informację, którą bezpośrednio przekazuje, jak i relacyjny, który wyraża uczucia mówiącego do drugiej strony ${ }^{9}$. Czasami dla stron kluczowy jest wymiar treściowy, a czasami relacyjny. Bywa też, że każda ze stron koncentruje się na innym wymiarze komunikacji. Warto też zwrócić uwagę, że komunikacja często polega na jednoczesnym przekazywaniu różnych komunikatów różnym odbiorcom ${ }^{10}$. Wyraźnie widać to $\mathrm{w}$ mediacji, gdzie strony konfliktu mogą oficjalnie zwracać się do mediatora - choć w rzeczywistości przekazują komunikaty do siebie nawzajem - lub odwrotnie, czyli zwracają się do drugiej strony, myśląc o tym, jak ich komunikat odbierze mediator.

\section{Konstruowanie rzeczywistości w procesie porozumiewania}

Zgodnie z założeniami konstrukcjonizmu społecznego człowiek nie żyje w obiektywnej rzeczywistości, lecz konstruuje ją w interakcji z innymi ludźmi i poprzez wspólne z nimi działania ${ }^{11}$. Ludzie postrzegają otaczający ich świat na swój własny sposób. Obraz rzeczywistości jest filtrowany przez zmysły, wiedzę, doświadczenie, stan ducha, system wartości, wyobrażenia o świecie etc. Zgodnie z koncepcją Paula Watzlawicka można wyróżnić dwa poziomy rzeczywistości - określane jako „rzeczywistość pierwszego i drugiego stopnia”. Do rzeczywistości pierwszego stopnia należą fizycznie obserwowalne cechy rzeczy lub sytuacji (fakty i obiekty), w rzeczywistości drugiego stopnia sami przypisujemy znaczenie rzeczom i sytuacjom pierwszego stopnia (interpretacje). Rzeczywistości tej nie tworzą obiekty ani zdarzenia, lecz jest ona osadzona w naszym umyśle ${ }^{12}$. W efekcie takiego ukształtowania systemu poznawczego każdy człowiek funkcjonuje we własnej, odrębnej rzeczywistości. Problemy komunikacyjne generuje to, że ludzie bardzo często nie odróżniają faktów od interpretacji, a swój model świata traktują jako jedyną „prawdziwą” rzeczywistość ${ }^{13}$. 
Wymiar konstrukcyjny ma już sam akt spostrzegania. Badacze zgadzają się, że na percepcję składa się kilka etapów: ukierunkowanie uwagi (inaczej selekcja lub dostrzeganie), organizacja zebranych danych i wreszcie ich interpretacja. Niektórzy badacze dodają także czwarty etap tworzenia się postrzeżeń, czyli negocjacje. Etapy te mogą pojawiać się w różnych sekwencjach. Na ukierunkowanie uwagi może wpływać interpretacja już zebranych danych, zaś wspólnie ustalona na etapie negocjacji narracja może ukierunkować zarówno uwagę, jak i organizację oraz interpretację płynących $\mathrm{z}$ otoczenia bodźców. Układ etapów percepcji ma zatem do pewnego stopnia charakter dynamiczny ${ }^{14}$. Sposób, w jaki selekcjonujemy, organizujemy i interpretujemy dane, zależy od czynników fizjologicznych (takich jak: funkcjonowanie zmysłów, wiek, stan zdrowia, poziom zmęczenia, zaspokojenie podstawowych potrzeb, jak np. głód czy pragnienie, cykl biologiczny/dobowy/hormonalny etc.), psychicznych (takich jak: nastrój, stan emocjonalny, obraz samego siebie, poczucie własnej wartości etc.), społecznych (takich jak: pozycja człowieka w społeczeństwie, płeć i role przypisane płci, role zawodowe etc.) i kulturowych ${ }^{15}$. Każdą sytuację interpersonalną można opisać na kilka sposobów. Każdy człowiek ma własny sposób widzenia świata.

Puntem wyjścia procesu postrzegania jest selekcja danych. Ludzie są codziennie bombardowani przez tysiące bodźców, których ich aparat zmysłowy nie jest w stanie przetworzyć. To, co zauważają, zależy w dużej mierze od ich motywacji i koncentracji uwagi - zgodnie z generalnym założeniem, że człowiek znajduje to, czego oczekuje ${ }^{16}$. Na selekcję danych wpływa także stan ducha postrzegającego, jego postawy, oczekiwania, doświadczenia oraz stan emocjonalny ${ }^{17}$. Na etapie selekcji odbiorcy upraszczają i eliminują pewne dane, tak aby całość zebranych informacji pozostawała spójna. Te informacje, które system nerwowy odbiera, są dalej upraszczane - przede wszystkim poprzez eliminowanie danych niespójnych z tymi, które dominują w przekazie ${ }^{18}$.

Zebrane $z$ otoczenia dane są organizowane przy wykorzystaniu schematów spostrzeżeniowych, czyli struktur poznawczych pozwalających na

Por. R. B. Adler, L. Rosenfeld, R. Proctor II, Relacje interpersonalne..., dz. cyt., s. 99; S. P. Morreale, B.H. Spitzberg, J.K. Barge, Komunikacja między ludźmi..., dz. cyt., s. 98.

18 Por. M. McKay, M. Davis, P. Fanning, Sztuka skutecznego porozumiewania się..., dz. cyt., s. 172. 
uporządkowanie informacji w ramach zgeneralizowanych, spójnych i znaczących wzorców, takich jak np. prototypy, skrypty i stereotypy ${ }^{19}$. Uporządkowanie zebranych danych poprzez wpisanie ich w jakiś posiadany schemat poznawczy (taki jak np. prototyp „ojciec” - w domyśle: skupiony na pracy, niemający czasu dla dzieci, skrypt pt. „odbieranie dzieci z przedszkola” czy stereotyp pt. „roztargniony naukowiec”) sprawia, że umysł dokonuje pewnych uogólnień na temat zaobserwowanej osoby i sytuacji, „dopasowując” zebrane dane tak, by jak najlepiej pasowały do posiadanego wzorca. Jak wskazują Lewicka i Wojciszke: „Wpływ schematów na rozumienie zdarzeń czy działań i formułowanie sądów ma $\mathrm{z}$ reguły charter asymilacji: wieloznaczne dane zostają «podciągnięte» pod schemat, a w konsekwencji ta sama informacja może zostać różnie zrozumiana w zależności od schematu, przez pryzmat którego jest interpretowana" ${ }^{20}$. Dane zebrane na podstawie obserwacji mężczyzny, który spóźnia się po dziecko do przedszkola, mogą równie dobrze zostać wpisane w schemat „roztargnionego naukowca”, jak i „nieodpowiedzialnego ojca”. W zależności od przyjętego schematu poznawczego postrzeganie danej sytuacji (i stosunek obserwatora/obserwatorki do obserwowanego mężczyzny) może się bardzo różnić. Inne będą dane towarzyszące, na które zwrócona zostanie uwaga, inny będzie też obraz, jaki zostanie w pamięci.

Do etapu organizacji danych należy także postrzeganie przyczyn i skutków danych zjawisk, czyli tzw. akcentowanie, rozumiane przez Watzlawicka jako „różnice w spostrzeganiu następstwa przyczyn i skutków w ciągu interakcji”"21. W zależności od sposobu uporządkowania przyczyn i skutków obraz postrzeganej sytuacji może być zupełne inny. Wyobraźmy sobie sytuacje, w której konflikt między małżonkami dotyczy niechęci ojca do odbierania dzieci z przedszkola. Za każdym razem, kiedy - po długich sporach między rodzicami - ojciec pojawia się w przedszkolu, żeby odebrać dzieci, one na widok taty zaczynają płakać. W zależności od przyjętego akcentowania dane te mogą być uporządkowane w różne sekwencje, np.:

- Ponieważ ojciec niechętnie odbiera dzieci z przedszkola, dzieci to wyczuwają i za każdym razem, kiedy po nie przychodzi, są podenerwowane i płaczą.

19 Por. S.P. Morreale, B. H. Spitzberg, J. K. Barge, Komunikacja między ludźmi..., dz. cyt., s. 101.

20 M. Lewicka, B. Wojciszke, Wiedza jednostki i sądy o świecie spotecznym..., dz. cyt., s. 37.

21 P. Watzlawick, J. Beavin, D. Jackson, Pragmatics of human communication: A study of interactional patterns, pahologis and paradoxes, New York: Norton 1967, s. 32 i nast. 
- Ponieważ za każdym razem, kiedy ojciec przychodzi po dzieci do przedszkola, one reagują na to podenerwowaniem i płaczem, on bardzo niechętnie odbiera dzieci.

Oczywiście sposób organizacji danych wpływa na ich późniejszą interpretację.

Interpretacja, czyli nadanie sensu zebranym informacjom, jest kolejnym etapem po selekcji i organizacji danych. Na ogół bazuje ona na ukrytych teoriach osobowości oraz teorii atrybucji, która dostarcza ram pozwalających na określenie motywów, które leżą u postaw zachowania innych ludzi ${ }^{22}$. Na interpretację mogą wpływać takie czynniki jak: stopień zaangażowania w relację z daną osobą, satysfakcja z relacji, wcześniejsze doświadczenia, założenia dotyczące ludzkich zachowań, oczekiwania, wiedza o innych ludziach etc. ${ }^{23}$ Zebrane informacje są interpretowane przez pryzmat zastosowanych schematów poznawczych: obserwator łatwiej wybaczy niepunktualność „,roztargnionemu naukowcowi” niż „nieodpowiedzialnemu ojcu”.

Jeżeli jakaś informacja może być interpretowana przez pryzmat dwóch lub więcej schematów, to dominuje ten $\mathrm{z}$ nich, od którego użycia upłynęło najmniej czasu. Jeśli np. kobieta na co dzień boryka się z zachowaniami swojego partnera, które ocenia jako nieodpowiedzialne, obserwując w przedszkolu ojca spóźniającego się po swoje dziecko, łatwiej zinterpretuje tą sytuację zgodnie ze schematem „nieodpowiedzialnego ojca”. Przedpercepcyjna aktywizacja schematu jest tym bardziej prawdopodobna:

- im silniejsze jest subiektywne oczekiwanie pojawienia się w otoczeniu egzemplarzy tego schematu;

- im silniej egzemplarze tego schematu powiązane są z realizacją celów i motywów podmiotu;

- im krótszy czas upłynął od poprzedniego zaktywizowania schematu;

- im częściej dany schemat był aktywizowany w przeszłości ${ }^{24}$.

Etap negocjacji to czas, w którym osoby porozumiewające się wzajemnie oddziałują na swoje spostrzeżenia. Oddziaływanie to pozwala na wspólne tworzenie pewnego znaczenia, które jest zarówno w ludziach, jak i między nimi $^{25}$. Na tym etapie ludzie mogą także budować wspólny obraz rzeczywistości, inaczej mówiąc, mogą konstruować wspólną narrację. Co ciekawe,

Por. S. P. Morreale, B. H. Spitzberg, J. K. Barge, Komunikacja między ludźmi..., dz. cyt., s. 103-104.

Por. R. B. Adler, L. Rosenfeld, R. Proctor II, Relacje interpersonalne..., dz. cyt., s. 98-99.

24 Por. M. Lewicka, B. Wojciszke, Wiedza jednostki i sądy o świecie społecznym..., dz. cyt., s. 44-45.

25 Por. R. B. Adler, L. Rosenfeld, R. Proctor II, Relacje interpersonalne..., dz. cyt., s. 95-96. 
badania wykazują, że satysfakcjonująca strony wspólna narracja wcale nie musi być zgodna z intersubiektywnie postrzeganą rzeczywistością, np. choć szczęśliwe małżeństwa z długim stażem charakteryzuje na ogół posiadanie wspólnej narracji, to nie zawsze jest ona w pełni spójna z faktycznym przebiegiem wydarzeń ${ }^{26}$.

Warto w tym miejscu zwrócić uwagę na kategorię, która w istotny sposób wpływa na proces komunikacji. Jest nią cecha płci. Płeć jest jedną z podstawowych kategorii sytuujących jednostkę w strukturze społecznej oraz istotnie kształtujących jej sposób myślenia i zachowania. Co ważne, jest to ten aspekt wpływu na komunikację, który dla wielu jej uczestników jest przezroczysty. Jak wskazuje Deborah Tannen: „Konstytuujemy kobiecość i męskość przez nasz sposób zachowania, cały czas będąc przekonani, że po prostu zachowujemy się «naturalnie»" ${ }^{27}$. Dojście do porozumienia kobiety i mężczyzny wymaga uświadomienia sobie relatywności i równorzędności różnych sposobów myślenia i odbierania, a także stylów poznawczych ${ }^{28}$. Jedną z bardziej znaczących różnic w postawach komunikacyjnych kobiet i mężczyzn jest sposób, w jaki odnoszą się oni do wymiaru treściowego i relacyjnego przekazywanego komunikatu. Badania wskazują, że kobiety częściej koncentrują się na wymiarze relacyjnym wiadomości, czyli ukrytej informacji na temat emocji, postaw i relacji między rozmówcami, natomiast mężczyźni przywiązują wagę przede wszystkim do dosłownego znaczenia treści komunikatu ${ }^{29}$. Opisany mechanizm sprawia, że rozmówcy różnej płci mogą zupełnie inaczej odbierać prowadzoną konwersacje, a w przypadku braku interwencji na rzecz przywrócenia „wspólnego gruntu” w rozmowie może to łatwo doprowadzić do nieporozumienia. W tym miejscu podkreślenia wymaga fakt, że wyniki badań nie uprawomocniają wniosku, że wszystkie kobiety i wszystkich mężczyzn charakteryzują odmienne style komunikacyjne, właściwe dla ich płci. Opisane prawidłowości nie przekreślają możliwości kompetentnego prowadzenia przez kobiety rzeczowego dialogu oraz przejawiania przez mężczyzn zrozumienia dla emocji.

Por. R. B. Adler, L. Rosenfeld, R. Proctor II, Relacje interpersonalne..., dz. cyt., s. 100-101.

D. Tannen, Ty nic nie rozumiesz! Kobieta i mężczyzna w rozmowie, Zysk i S-ka, Poznań 1999, s. 307.

Por. K. Weryk, Kobieta i mężczyzna - odwieczny dylemat komunikacyjny, w: Paradygmaty ipułapkipsychologii komunikowania się, red. T. Rzepa, Wydawnictwo Naukowe Scholar, Szczecin 2006, s. 18.

29 Por. D. Tannen, To nie tak! Jak styl konwersacyjny ksztattuje relacje z innymi, Zysk i S-ka, Poznań 2002. 


\section{Dobra komunikacja i jej zakłócenia}

Po przyjęciu założenia, że komunikacja międzyludzka ma charakter interakcyjny, a rzeczywistość stron jest konstruowana w procesie porozumiewania się, kolejnym krokiem będzie zdefiniowanie, czym jest dobra komunikacja. A idąc dalej, jaka komunikacja będzie pomocna w wychodzeniu z konfliktu i jaką komunikacje powinien wspierać mediator pomagający stronom w mediacji. W niniejszych rozważaniach przyjęto założenie, że dobra komunikacja to taka, która jest skuteczna (czyli realizuje cele przyjęte przez jej uczestników) i stosowna (tzn. sposób jej realizacji jest adekwatny do norm społecznych ogólnie przyjętych w danym kontekście sytuacyjnym) ${ }^{30}$. W codziennym życiu ludzie - w sposób uświadomiony lub nie - przyjmują różne cele komunikacyjne. Celem może być np. przekazanie komunikatu, budowanie relacji, a także przewentylowanie emocji. Wbrew potocznym intuicjom nie zawsze do celów komunikacji będzie należało wzajemne zrozumienie. W teorii komunikacji wskazuje się, że istnieją rodzaje porozumiewania, w których zrozumienie nie jest zasadniczym celem jej uczestników. Są to np. rytuały społeczne (jak wymiana uprzejmości przy przywitaniu, czy tzw. small-talki), próby wywierania wpływu na innych, jak również celowa dwuznaczność lub fałsz ${ }^{31}$.

Na potrzeby prowadzonych analiz przyjęto założenie, że w przypadku komunikacji, jaka ma miejsce w mediacji, wiodącym celem komunikacyjnym - obok osiągnięcia porozumienia - będzie właśnie zbudowanie wzajemnego zrozumienia stron. Choć można sobie wyobrazić, że w pewnych skrajnych sytuacjach możliwe będzie osiągniecie porozumienia bez wzajemnego zrozumienia, to można mieć wątpliwość, czy istotnie porozumienie takie będzie trwałe i w pełni dla stron satysfakcjonujące. Co do zasady komunikacja w mediacji powinna się więc opierać na wzajemnym zrozumieniu. Podsumowując: dobra komunikacja w mediacji będzie oznaczać taką komunikację między stronami, która pozwoli na wzajemne zrozumienie, którego efektem może być dojście do porozumienia bez pogorszenia się relacji między nimi. Tak zdefiniowana dobra komunikacja nie może co prawda zagwarantować, że konflikt zostanie złagodzony lub rozwiązany, ale - jak podkreślają

30 Por. S.P. Morreale, B.H. Spitzberg, J. K. Barge, Komunikacja między ludźmi..., dz. cyt., s. 65.

31 Por. R. B. Adler, L. Rosenfeld, R. Proctor II, Relacje interpersonalne..., dz. cyt., s. 17. 
teoretycy przedmiotu - „zła komunikacja w dużym stopniu zwiększa prawdopodobieństwo kontynuacji lub zaostrzenia konfliktu" ${ }^{32}$.

Ludzie funkcjonują w swoich subiektywnych rzeczywistościach (zwanych też kontekstami), opartych na niepowtarzalnych zestawieniach wiedzy, doświadczeń, cech osobistych etc. Czasami te konteksty mogą być podobne, czasami bardzo się od siebie różnią. Im bardziej odmienne konteksty czy też środowiska komunikacyjne, z jakich wywodzą się uczestnicy komunikacji, tym łatwiej o nieporozumienia. Nawet jednak w przypadku osób pochodzących z podobnych środowisk wzajemne zrozumienie może zakłócić wiele czynników, czyli tzw. szumów komunikacyjnych. Trzy podstawowe grupy zakłóceń to: szumy zewnętrzne (jak np. hałas, niesprzyjająca temperatura, bodźce zakłócające uwagę etc.), szumy fizjologiczne (jak np. choroba, silne emocje, zaburzenia zmysłów, zmęczenie etc.) oraz szumy psychologiczne (będące np. efektem działania omawianych wcześniej mechanizmów poznawczych) ${ }^{33}$. W przypadku konfliktów szczególnie istotny wydaje się obszar działania czynników poznawczych. Tym bardziej że jest to przestrzeń, której nie dostrzegamy w bezpośrednim odbiorze - tak jak zmysłowo odbieramy potencjalne źródła szumów zewnętrznych lub fizjologicznych. Przetwarzanie poznawcze to obszar funkcjonowania, którego mechanizmów działania ludzie nie są w pełni świadomi. Tym bardziej trudno im uchwycić tkwiące w ich własnym myśleniu źródła błędów i nieporozumień komunikacyjnych. Dlatego też tak ważne wydaje się rozpoznanie mechanizmów stojących za poznawczymi „szumami psychologicznymi”, aby możliwe było lepsze rozumienie przyczyn ewentualnych impasów komunikacyjnych bądź eskalacji konfliktu i adekwatne przeciwdziałanie ich wpływowi.

Konflikt jest jedną z sytuacji, w których procesy percepcyjne mogą prowadzić do nieadekwatnego - tj. niezgodnego z intencjami nadawcy czy téz oceną zewnętrznego obserwatora - odbioru komunikatów. Mechanizmy poznawcze, które na co dzień działają w sposób przystosowawczy i ułatwiający sprawne funkcjonowanie, w sytuacji konfliktu mogą prowadzić do poważanych zaburzeń odbioru rzeczywistości. Tendencyjności poznawcze - wzmacniane m.in. poprzez negatywne nastawienie, napięcie emocjonalne i nieprzyjemne emocje (niepokój, lęk, złość etc.) - mogą prowadzić do

R. M. Krauss, E. Morsella, Konflikt a komunikacja, w: M. Deutsch, P. T. Coleman, Rozwiazywanie konfliktów. Teoria i praktyka, Wydawnictwo Uniwersytetu Jagiellońskiego, Kraków 2005, s. 143.

Por. R. B. Adler, L. Rosenfeld, R. Proctor II, Relacje interpersonalne..., dz. cyt., s. 17. 
przekłamywania odbieranych komunikatów, myślenia stereotypowego i rosnącej polaryzacji stanowisk ${ }^{34}$. Co więcej, tam, gdzie pojawiają się ważne interesy, jednostka ma tendencję do przyjmowania postawy egocentrycznej, co również nie wspiera budowania wzajemnego zrozumienia. Jeśli dodamy do tego spowodowane długotrwałym konfliktem osłabienie energetyczne stron, przejawiające się w zmęczeniu, większej drażliwości i mniejszej otwartości na spojrzenie drugiej strony oraz potencjalny brak zasobów kompetencyjnych w obszarze komunikacji, nie dziwi fakt, że wzajemne zrozumienie się skonfliktowanych osób staje się wydatnie utrudnione.

Nieporozumienia między stronami narastają w miarę trwania konfliktu, prowadząc do powstania tzw. przepaści percepcyjnej ${ }^{35}$, kiedy to kontekst doświadczeń, przekonań i postaw stron konfliktu zaczyna się od siebie skrajnie różnić, a każdy kolejny komunikat - odbierany zgodnie z aktualnym nastawieniem percepcyjnym - dodatkowo te różnice pogłębia. Istnienie „przepaści percepcyjnej” znacząco utrudnia możliwość adekwatnego zrozumienia komunikatu drugiej strony, a tym bardziej wspólnego wypracowania znaczenia przekazywanych komunikatów. Dochodzi do sytuacji, w której zaczynają funkcjonować dwie równoległe narracje - na ogół każda z nich jest nakierowana na podważenie narracji drugiej strony. Aby możliwe było zasypanie owej „przepaści percepcyjnej”, konieczne jest zrozumienie mechanizmów odpowiadających za jej zaistnienie.

\section{Czynniki odpowiedzialne za powstawanie „przepaści percepcyjnej"}

\section{Schematy poznawcze}

Dla wyjaśnienia, dlaczego procesy poznawcze mogą destrukcyjnie wpływać na proces budowania zrozumienia, niezbędny jest powrót do koncepcji schematów poznawczych. Ludzie mają tendencję do dbania o spójność posiadanego systemu przekonań. Posiadane przez nich schematy poznawcze działają jak

34 Por. L. Thompson, J. Nadler, Tendencyjność sądów wrozwiązywaniu konfliktów. Jakjąpokonywać, w: M. Deutsch, P. T. Coleman, Rozwiazywanie konfliktów. Teoria i praktyka, Wydawnictwo Uniwersytetu Jagiellońskiego, Kraków 2005, s. 214.

35 Pojęcie zostało zapożyczone z książki: R. B. Adler, L. Rosenfeld, R. Proctor II, Relacje interpersonalne..., dz. cyt., s. 94 . 
filtry, które odsiewają informacje sprzeczną lub niespójną z dominującym motywem ${ }^{36}$. Ludzie trwają przy z góry przyjętych założeniach (czyli schematach) nawet wtedy, gdy mają do czynienia z informacjami wyraźnie z nimi niezgodnymi. Przejawem tego może być konserwatyzm poznawczy (opisany szerzej poniżej), a także efekt uporczywości, polegający na tym, że przekonania ludzi dotyczące ich samych i świata społecznego utrzymują się nawet wtedy, gdy dane wspierające te przekonania zostały podważone ${ }^{37}$. Umysł ludzki działa w taki sposób, że dane wpisujące się w schematy są łatwiej zauważane, lepiej pamiętane i uznawane za ważniejsze. Natomiast informacje niezgodne z przekonaniami częściej zostają przeoczone, zapomniane lub uznane za nieistotne.

W sytuacji konfliktu - zwłaszcza długotrwałego i dotyczącego kwestii znaczących dla danej osoby - najłatwiej dostępne stają się schematy bazujące na negatywnym obrazie drugiej strony i jej zachowań. Złe doświadczenia prowadzą do wytworzenia obrazu drugiej strony jako złej lub niemoralnej, a jej działania z założenia odbierane są jako wrogie. Na przykład, jeśli żona ma schemat męża jako nieodpowiedzialnego ojca, to będzie dostrzegać (a następnie przywoływać z pamięci) wszystkie te przypadki, kiedy źle ubrał dziecko, nie spełnił danej obietnicy lub pozwolił zjeść słodycze przed obiadem - nawet gdyby w istocie zdarzało mu się to nie częściej niż innym rodzicom. Nie będzie natomiast zauważać przejawów tego, że mąż troszczy się i dba o dzieci. Wybiórcze dostrzeganie i pamiętanie będą zwrotnie wzmacniały istniejący schemat i eliminowały inne schematy znajdujące potencjalnie zastosowanie w danej sytuacji.

Schematy poznawcze bardzo mocno wpływają na postrzeganie rzeczywistości, nie są jednak strukturą nienaruszalną. W pewnych okolicznościach możliwe jest ich przezwyciężenie. Na podstawie badań wskazano trzy grupy takich okoliczności:

- Ludzie są bardziej elastyczni poznawczo, kiedy nie są pewni, czy ich schemat jest trafny.

- Jeśli jakaś informacja wydaje się skrajnie sprzeczna ze schematem i nie jest możliwe jej automatyczne zasymilowanie, ludzie dokonują świadomych wysiłków intelektualno-poznawczych, starając się ją wyjaśnić lub w jakiś sposób pogodzić z posiadanym systemem przekonań.

36 Por. E. Aronson, T. D. Wilson, R. M. Akert, Psychologia społeczna. Serce i umyst, Zysk i S-ka, Poznań 1997, s. 128-129.

Por. E. Aronson, T.D. Wilson, R. M. Akert, Psychologia spoteczna..., dz. cyt., s. 142. 
- Większa gotowość do ewentualnej redefinicji poznawczej ma miejsce wówczas, gdy ze względu np. na ocenę zewnętrzną lub konieczność obrony swojego stanowiska ważne jest, żeby schematy były trafne ${ }^{38}$.

Wydaje się, że powyższe okoliczności stwarzają przestrzeń umożliwiającą oderwanie się od destrukcyjnie działających automatyzmów poznawczych na rzecz świadomego tworzenia bardziej adekwatnych struktur organizowania i interpretacji danych. Znajomość tych mechanizmów jest szczególnie istotna z perspektywy mediatora, dla którego odpowiednie zdiagnozowanie sytuacji i zastosowanie we właściwym momencie adekwatnych narzędzi wspierania komunikacji jest warunkiem skuteczności prowadzonych działań.

\section{Wpływ posiadanego obrazu siebie na postrzeganie świata}

Na sposób postrzegania świata i siebie w tym świecie wpływa sposób widzenia samego siebie. Własny obraz to względnie stały zestaw wyobrażeń na własny temat. Ludzie mają tendencję do poszukiwania informacji potwierdzających posiadany przez nich obraz samych siebie - niezależnie od tego, czy ma on charakter pozytywny, czy negatywny. Tendencję tę nazywamy konserwatyzmem poznawczym ${ }^{39}$.

Jednym z elementów tworzących obraz samego siebie jest poczucie własnej wartości, które może mieć istotny wpływ na zachowania związane z porozumiewaniem $\operatorname{się~}^{40}$. W literaturze wskazuje się, że jednym z czynników najsilniej wpływających na ludzkie zachowania jest występująca u większości ludzi potrzeba myślenia o sobie jak najlepiej, tj. podtrzymywania względnie wysokiego poziomu samooceny ${ }^{41}$. Uczucie przykrego napięcia wynikające $z$ informacji, które naruszają pozytywny obraz samego siebie jako osoby rozsądnej i przyzwoitej, nazywa się dysonansem poznawczym. Ludzie z natury dążą do redukcji dysonansu poznawczego i zachowania pozytywnego obrazu samych siebie. Jest to możliwe albo poprzez zmianę zachowania, albo poprzez jego uzasadnienie ${ }^{42}$.

Cyt za: E. Aronson, T. D. Wilson, R. M. Akert, Psychologia społeczna. Serce i umyst, Zysk i S-ka, Poznań 1997, s. 147.

39 Por. R. B. Adler, L. Rosenfeld, R. Proctor II, Relacje interpersonalne..., dz. cyt.

40 Por. R. B. Adler, L. Rosenfeld, R. Proctor II, Relacje interpersonalne..., dz. cyt., s. 65.

41 Por. E. Aronson, T. D. Wilson, R. M. Akert, Psychologia spoteczna. Serce i umyst..., dz. cyt., s. 137.

42 Por. E. Aronson, T. D. Wilson, R. M. Akert, Psychologia spoteczna. Serce i umyst..., dz. cyt., s. 82. 
W konfliktach dobrze widać oddziaływanie zjawiska dysonansu poznawczego, szczególnie w sytuacjach, gdy stykają się dwie skrajne oceny jakiegoś zachowania. Można to zaobserwować na przykładzie sporu o kontakty rodzicielskie. Kobieta uważa się za dobrą i troskliwą matkę, która w trosce o dzieci ogranicza ich kontakty z nieodpowiedzialnym ojcem, nie dbającym o ich zdrowie (nieadekwatnie ubieranie dzieci na spacery, niekarmienie o właściwych porach etc.) i potrzeby (spóźnianie się i odwoływanie spotkań). Mężczyzna uważa się za dobrego i troskliwego ojca, który próbuje wyrwać dzieci spod wpływu nadopiekuńczej i przesadnie kontrolującej matki. Z perspektywy kobiety sygnał, że jest nadopiekuńcza i nadmiernie kontrolująca, będzie zaburzał jej wysoką samoocenę w roli matki. Podobnie z perspektywy ojca opinia, że jest on nieodpowiedzialny i nie dba o dzieci, narusza jego samoocenę w roli ojca. Zapewne żadne z rodziców nie będzie gotowe na przyznanie racji drugiej stronie i zmianę zachowania. Można się spodziewać, że będą raczej zmierzali do uzasadnienia własnego zachowania poprzez odwołanie do mechanizmów poznawczych, np. deprecjacje drugiej strony i jej opinii („Zawsze była histeryczką, nie ma co jej słuchać” versus: „Nie interesuje mnie stanowisko tego człowieka, mówi to tylko po to, żeby mi dokuczyć”) i uskrajnianie własnego stanowiska („Nie tylko jest nadopiekuńcza i kontrolująca, ale do tego okropna z niej manipulantka” oraz: „Nie tylko jest nieodpowiedzialny i interesują go tylko własne potrzeby, ale jeszcze jest okropnym kłamcą”).

Ludzie zaangażowani $\mathrm{w}$ redukowanie dysonansu są tak zajęci przekonywaniem samych siebie, że zawsze postępują i postępowali właściwie, iż często prowadzi to do zachowań irracjonalnych i dezadaptacyjnych ${ }^{43}$. Efektem dążenia do redukcji dysonansu może być powiększenie się przepaści percepcyjnej między stronami i zmniejszenie szans na adekwatne odebranie komunikatu drugiej strony. Zjawisko to psychologowie społeczni określają mianem pułapki racjonalizacji. Polega ona na tym, że w wyniku zmniejszania dysonansu (czyli zmierzania do spójności obrazu samych siebie) ludzie wikłają się w sieć zniekształceń, która uniemożliwia im adekwatne spojrzenie na rzeczywistość. Co więcej, proces usprawiedliwienia samych siebie może doprowadzić do całkowitego obniżenia samooceny ${ }^{44}$. Wracając do sytuacji z opisywanego przykładu konfliktu rodzicielskiego, po paru miesiącach sporu kobieta może uświadomić sobie, że odseparowując dzieci od ojca, głęboko

43 Por. E. Aronson, T. D. Wilson, R. M. Akert, Psychologia spoteczna. Serce i umyst..., dz. cyt., s. 83. 44 Por. E. Aronson, T. D. Wilson, R. M. Akert, Psychologia spoteczna. Serce i umyst..., dz. cyt., s. 119. 
je unieszczęśliwia. Mężczyzna może z kolei dostrzec, że obrażanie matki w obecności dzieci prowadzi do tego, że dzieci zaczynają się go bać i niekoniecznie lubią z nim przebywać. W efekcie obie strony mogą poczuć się bardzo kiepskimi rodzicami, a ich samoocena mocno na tym ucierpi.

Mechanizm dążenia do redukcji dysonansu poznawczego uruchamia się również w sytuacjach, w których ludzie poświęcają na coś bardzo wiele zasobów: czasu, energii bądź pieniędzy, dlatego oczekują efektów swoich wysiłków lub przynajmniej potwierdzenia słuszności ich ponoszenia. Jeśli zatem ktoś angażuje wszystkie swoje siły w prowadzenie konfliktu - budując sieć wsparcia wśród rodziny i znajomych, inicjując postępowanie sądowe etc. - to będzie zarazem zmierzał do wykazania słuszności podejmowanych przez siebie wysiłków. Będzie zatem dostrzegać wszystkie te sygnały, płynące $z$ otoczenia i od przeciwnika, które potwierdzą słuszność prowadzonej przez niego walki. Motywacją do tego typu zniekształceń może być dysonans wzbudzony przez potrzebę uzasadnienia wysiłku ${ }^{45}$. Warto podkreślić, że im ważniejsza i bardziej nieodwołana decyzja, tym większa potrzeba redukcji dysonansu. W konfliktach rodzinnych stawka na ogół jest wysoka, a spory dotyczą spraw egzystencjalnych - czy to w obszarze uczuć i relacji, czy to w sferze materialnej. Stąd większa szansa na to, że uczestnicy będą dokonywać manipulacji poznawczych (niekoniecznie świadomych), mających na celu redukcję odczuwanych dysonansów.

Redukcja dysonansu poznawczego odbywa się na ogół na poziomie przetwarzania poznawczego (lub znacznie rzadziej w obszarze zmiany zachowań). Krok dalej idzie mechanizm zwany samospełniającą się przepowiednią, obserwowany wyraźnie także na poziomie zachowań. Tutaj oczekiwania danej osoby prowadzą do zachowywania się w konkretny sposób, co kolei zwiększa prawdopodobieństwo, że oczekiwane zdarzenie w rzeczywistości będzie miało miejsce. Samospełniające się proroctwo opiera się na następującej sekwencji wydarzeń:

- określone oczekiwanie (wobec siebie lub innej osoby);

- zachowanie zgodne z tym oczekiwaniem;

- urzeczywistnienie oczekiwania;

- wzmocnienie pierwotnego przekonania.

Co do zasady wpływ samospełniających się proroctw na porozumiewanie się ludzi może być zarówno pozytywny, jak i negatywny. Jednak w sytuacji

45 Por. E. Aronson, T.D. Wilson, R. M. Akert, Psychologia społeczna. Serce i umyst..., dz. cyt., s. 93. 
konfliktu, kiedy oczekiwania stron wobec siebie mają w większości charakter negatywny, samospełniające się proroctwo będzie na ogół prowadziło do pogłębienia konfliktu i pogorszenia relacji. Przykładowo, jeśli w toku rozmów rodzeństwa na temat opieki nad niesprawną matką siostra z góry założy, że brat jest niechętny do pomocy, to może w oparciu o te założenia (i towarzyszącą im negatywną ocenę brata jako człowieka) odnosić się do niego w tak nieprzyjemny sposób, że nawet jeśli wyjściowo brat brał pod uwagę wzięcie na siebie części zadań opiekuńczych, to po tym, jak zostanie przez siostrę kilkakrotnie obrażony i upokorzony, może zmienić zdanie - co w efekcie potwierdzi negatywne zdanie, jakie miała o nim siostra. Samospełniające się proroctwo jest zjawiskiem występującym w mediacji bardzo często. Jeśli uczestnicy oczekują od innych określonego zachowania, to bardzo często - za pomocą subtelnych sygnałów - przekazują im swoje oczekiwania, zwiększając w ten sposób prawdopodobieństwo wystąpienia przewidywanego zachowania.

Wśród procesów poznawczych, które mają na celu ochronę samooceny, warto przywołać jeszcze jeden, o charakterze nieco paradoksalnym. Ze względu na potrzebę zachowania spójności ludzie mają tendencje do takiego postrzegania rzeczywistości, które będzie podtrzymywać ich samoocenę, również wtedy, kiedy jest ona niska. Ludzie, którzy nisko się oceniają, są przekonani, że inni również nisko ich cenią. W związku z tym kierowane do nich komunikaty mogą odbierać jako krytykę, podważanie kompetencji, odrzucenie etc. Niskie poczucie własnej wartości może się również przejawiać zachowaniami wrogimi wobec rozmówcy, zgodnie z założeniem, że jeśli zostanie on poniżony, to na jego tle wypadnie lepiej ${ }^{46}$.

\section{Tendencyjności poznawcze}

Mechanizmy poznawcze odpowiadają zarówno za to, jak ludzie widzą samych siebie, jak i za to, jak postrzegają innych. W interpretowaniu zebranych danych opierają się często na tzw. teoriach atrybucji, czyli koncepcjach wyjaśniających przyczyny własnych zachowań lub zachowań innych ludzi. Teoria atrybucji - stworzona przez Fritza Heidera - zakłada, że wyjaśnienia mogą odwoływać się do właściwości osobistych, tj. postawy, charakteru czy osobowości (tzw. atrybucje wewnętrzne) lub do właściwości sytuacyjnych, 
czyli okoliczności wpływających na zachowanie (tzw. atrybucje zewnętrzne $)^{47}$. Wyjaśnienia przyczyn ludzkich zachowań są o tyle istotne, że pozwalają adekwatnie na nie reagować. Oczywiście adekwatność reakcji będzie zależała od tego, na ile trafne jest przyjęte wyjaśnienie. W zależności od tego, czy dane zachowanie zostanie uznane za wynikające z cech jednostki, czy z wpływu okoliczności zewnętrznych, reakcja emocjonalna może być bardzo różna. Przykładem może być sytuacja, w której mąż spóźnia się po dziecko do przedszkola. Jeśli żona uzna, że spóźnienie wynikało z okoliczności obiektywnych, takich jak np. nieoczekiwany wypadek na drodze (atrybucja zewnętrzna), to zapewne wykaże się zrozumieniem lub wręcz współczuciem. Natomiast w przypadku uznania, że spóźnienie męża wynika z typowej dla niego nieodpowiedzialności i lekceważenia terminów (atrybucja wewnętrzna, odwołująca się do właściwości osobistych), to zapewne wywoła negatywne uczucia: złość, żal, rozczarowanie. Za uczuciami tymi mogą pójść konkretne wypowiedzi lub zachowania, które z kolei mogą zostać odebrane przez drugą stronę jako całkowite niezrozumienie. Warto wskazać, że jeśli strony są w konflikcie, tendencja odwoływania się do posiadanych negatywnych schematów poznawczych jest tak silna, że nawet gdyby mąż wyjaśniał swoje spóźnienie wypadkiem, żona z dużym prawdopodobieństwem i tak odwoła się do posiadanego schematu „osoby nieodpowiedzialnej, która nie szanuje czasu innych”, stwierdzając np. że „zawsze jest jakiś wypadek”, „trzeba było przewidzieć sytuację na drodze, wiadomo, że zawsze coś może się zdarzyć" etc. Przytoczony przykład pokazuje, że dla sposobu odbierania rzeczywistości faktyczne okoliczności okazują się często znacznie mniej istotne niż wewnętrzna mapa poznawcza, do której są odnoszone.

Tendencyjności poznawcze z zasady mają charakter przystosowawczy. Jednak w praktyce nie zawsze prowadzą do takiego odbioru komunikatu, który jest zgodny z intencjami nadawcy, a ryzyko to wyraźnie się zwiększa w przypadku komunikacji stron będących w konflikcie. Psychologowie społeczni opisali wiele prawidłowości, których działanie może utrudniać wzajemne zrozumienie bądź budowanie przez strony wspólnej narracji. Poniżej przedstawiony zostanie przegląd najważniejszych z nich.

Podstawowy błąd atrybucji określa typową dla ludzi tendencję do wyjaśniania zachowań predyspozycjami osobistymi, przy pomniejszeniu lub pominięciu roli kontekstu sytuacyjnego. Co znaczące, prawidłowość ta

47 Por. F. Heider, The psychology of interpersonal relations, New York: Wiley 1958. 
znacznie rzadziej znajduje zastosowanie przy okazji wyjaśniania własnych zachowań $^{48}$. Wskazać można także zjawisko tendencyjności działającego i obserwatora opierającego się na tym, że cudze zachowanie częściej tłumaczymy przyczynami wewnętrznymi, własne zachowanie częściej tłumaczymy zewnętrznymi okolicznościami ${ }^{49}$.

Jak już wcześniej wspomniano, dla dobrostanu psychicznego człowieka istotne jest podtrzymanie dobrego mniemania o sobie. $\mathrm{W}$ przypadku, gdy z jakiegoś względu ta samoocena jest zagrożona, ludzie dokonują tzw. atrybucji w służbie ego, nazywanej także egotyzmem atrybucyjnym. Oznacza to, że swoje sukcesy przypisują czynnikom wewnętrznym, czyli np. zdolnościom, talentowi, pracowitości etc., a porażki tłumaczą czynnikami zewnętrznymi, czyli wpływem sytuacyjnym ${ }^{50}$. W konfliktach rodzinnych często dochodzi do toksycznej wymiany zdań, która bazuje na wymianie argumentów adpersonam, podważających dobre intencje, charakter i postawy drugiej osoby, co może być odbierane jako zagrożenie dla samooceny. Tym bardziej można się spodziewać uruchamiania mechanizmu egotyzmu atrybucyjnego.

W konflikcie wzrasta siła dwóch równoległych tendencyjności - doszukiwania się przyczyn wewnętrznych w negatywnych zachowaniach innych oraz przyczyn zewnętrznych w negatywnych zachowaniach własnych. $Z$ badań wynika, że strony będące w konflikcie częściej obwiniały partnera za zaistniałą sytuacje, niż brały odpowiedzialność za swoją rolę w konflikcie ${ }^{51}$. Występowanie tego mechanizmu jest również widoczne w sytuacjach trwałego konfliktu. Badacze wykazali m.in., że w związkach o dużym poziomie napięcia lub niezadowolenia strony konsekwentnie przypisywały negatywnie wartościowane zachowania partnera przyczynom wewnętrznym, pozostającym pod jego wpływem, a ewentualne zachowania pozytywne przyczynom zewnętrznym, nad którymi nie miał kontrolii ${ }^{52}$. Tendencja do doszukiwania się w zachowaniu osoby o coś oskarżanej przyczyn, na które miała wpływ, nazywana jest stronniczością oskarżającego. Postrzeganie

48 Por. E. Aronson, T. D. Wilson, R. M. Akert, Psychologia spoteczna. Serce i umyst..., dz. cyt., s. 196; 201.

Por. K. G. Allred, Złość i odwet w konflikcie. Znaczenie atrybucji, w: M. Deutsch, P. T. Coleman, Rozwiązywanie konfliktów. Teoria i praktyka, Wydawnictwo Uniwersytetu Jagiellońskiego, Kraków 2005 , s. 240.

Por. E. Aronson, T. D. Wilson, R. M. Akert, Psychologia spoteczna. Serce i umyst..., dz. cyt., s. 205;

M. Lewicka, B. Wojciszke, Wiedza jednostki i sady o świecie spotecznym..., dz. cyt., s. 64.

Por. K. G. Allred, Złość i odwet w konflikcie. Znaczenie atrybucji..., dz. cyt., s. 244. 
zachowania jako motywowanego wewnętrznie generuje w postrzegającym złość i chęć odwetu, a w dalszej perspektywie destrukcyjne działania i wypowiedzi. W efekcie oskarżający obarcza oskarżanego większą odpowiedzialnością, a oskarżony czuje się mniej odpowiedzialny za swoje zachowanie, niż sugerowałaby rzeczywista sytuacja.

Innym mechanizmem, który w znaczący sposób może utrudniać wzajemne zrozumienie stron, a tym bardziej osiągnięcie przez nie porozumienia, jest egocentryzm atrybucyjny. Zjawisko to opiera się na przypisywaniu sobie przez daną osobę większej odpowiedzialności za konsekwencje wspólnie wykonanej pracy, niż skłonny jest to stwierdzić postronny obserwator ${ }^{53}$. Działanie tego mechanizmu zostało wykazane m.in. przy okazji obserwacji podziału obowiązków domowych w parach małżeńskich i analizy tego, jak każdy z małżonków oceniał wkład swojej pracy. Każdy z małżonków uważał, że robił w domu znacznie więcej, niż dostrzegał drugi małżonek. Źródeł tego zjawiska badacze doszukują się w trzech obszarach:

- różnic w dostępie do informacji o wkładzie własnym i wkładzie partnera;

- procesów odpowiedzialnych za kodowanie i odtwarzanie informacji - lepiej zauważamy i zapamiętujemy to, co dotyczy naszego wkładu niż wkładu partnera;

- motywacyjnym - przypisywanie sobie większej odpowiedzialności za wynik podnosi samoocenę oraz wzmacnia poczucie sprawstwa.

Egocentryzm atrybucyjny w pisuje się w szersze zjawisko, jakim jest efekt fałszywej powszechności, czyli skłonność do przeceniania częstości własnych zachowań i niedoceniania częstości zachowań partnera interakcji ${ }^{54}$.

$\mathrm{Z}$ perspektywy prowadzenia mediacji szczególnie istotny wydaje się mechanizm tendencyjności atrybucji międzygrupowej. Nie dość, że źle ocenianemu zachowaniu osoby spoza swojej grupy częściej przypisywane są przyczyny natury wewnętrznej niż takiemu samemu zachowaniu członka grupy własnej $^{55}$, to jeszcze w przypadku grupy cudzej istnieje tendencja do odwoływania się do ogólnych kwantyfikatorów. Jak wskazują Robert M. Krauss i Ezequiel Morsella: „Każde interpersonalne działanie można scharakteryzować na różnych poziomach uogólnienia. Badania wykazują, że ludzie opisują

53 Por. M. Lewicka, B. Wojciszke, Wiedza jednostki i sądy o świecie społecznym..., dz. cyt., s. 65.

54 Por. M. Lewicka, B. Wojciszke, Wiedza jednostki i sady o świecie społecznym..., dz. cyt., s. 65-66.

55 R. B. Adler, L. Rosenfeld, R. Proctor II, Relacje interpersonalne..., dz. cyt., s. 240. 
działania członków grupy własnej i grupy obcej w sposób systematycznie odmienny. W przypadku działania ocenianego negatywnie zachowanie członków grupy obcej jest zwykle charakteryzowane na względnie wysokim poziomie abstrakcji, podczas gdy w przypadku członków grupy własnej jest opisane bardziej konkretnie. Wzorzec ten jest odwrócony w przypadku pozytywnie ocenianych zachowań" ${ }^{56}$.

Zjawisko to często obserwuje się w mediacji, gdzie skonfliktowani uczestnicy postrzegają drugą stronę jako przeciwnika, czyli „osobę spoza grupy własnej”. Można pokazać tą prawidłowość na przykładzie jednego z wątków sporu rodziców o ustalenie kontaktów z małoletnimi dziećmi: ojciec spóźnia się godzinę z odebraniem synów od matki. Matka, która planowała po odebraniu dzieci przez ojca wykonać pracę, stwierdza, że nie zdąży tego zrobić w skróconym przez spóźnienie czasie i postanawia przyjechać po dzieci do ojca o godzinę później, niż było to planowane, o czym go jednak nie informuje. Ojciec - zmuszony do czekania na matkę - nie zdąża na pociąg, na który miał już bilety.

W trakcie dyskusji strony co do zasady zgadzały się, co do faktów jednak swoje stanowiska odnosiły do zupełnie innego poziomu ogólności - opisując swoje zachowanie, przywoływały konkretne zachowanie, opisując zachowanie drugiej strony, przenosiły je na poziom bardzo dużej ogólności.

Punkt widzenia matki (wytłuszczone zostały komunikaty zaprezentowane w toku mediacji):

- Na temat zachowania drugiej strony: Ojciec spóźnił się godzinę z odbiorem synów. Ojciec zawiódł synów, którzy na niego czekali. Synowie nie mogą na ojca liczyć.

- Na temat własnego zachowania: Matka spóźniła się godzinę po odbiór synów. Matka zaburzyła plany ojca, który czekał na odbiór synów i spóźnił się na pociąg. Matka jest całkowicie nieprzewidywalna.

Punkt widzenia ojca (wytłuszczone zostały komunikaty zaprezentowane w toku mediacji):

- Na temat zachowania drugiej strony: Matka spóźniła się godzinę po odbiór synów. Matka zaburzyła plany ojca, który czekał na odbiór synów i spóźnił się na pociąg. Matka jest całkowicie nieprzewidywalna.

56 Por. R. M. Krauss, E. Morsella, Konflikt a komunikacja..., dz. cyt., s. 138. 
- Na temat własnego zachowania: Ojciec spóźnił się godzinę z odbiorem synów. Ojciec zawiódł synów, którzy na niego czekali. Synowie nie mogą na ojca liczyć.

Typowa dla komunikacji w konflikcie generalizacja przewin drugiej strony i podkreślanie wąskiego zakresu jej ewentualnych pozytywnych postępków silnie utrudnia budowanie przez strony wspólnej narracji. Buduje także nastawienie obronne, które uaktywnia opisane wyżej mechanizmy, wspierające zachowanie dobrej samooceny i podtrzymanie poczucia własnej wartości, co z kolei prowadzi do dalszego powiększenia „przepaści percepcyjnej” między stronami i ogranicza możliwości dobrej komunikacji, opartej na budowaniu wzajemnego zrozumienia.

Problem utrudniającym komunikację w konflikcie może być także zjawisko zniekształceń parataktycznych, polegające na tym, że na postrzeganie przez jednostkę bieżącej rzeczywistości wpływają wydarzenia z przeszłości. Nowo poznana osoba może np. przypominać kogoś znanego w przeszłości, co sprawia, że przenosi się na nią pozytywny lub negatywny stosunek wobec tamtej osoby. Obraz (na ogół negatywnych) wydarzeń w przeszłości rzutuje na postrzeganie tego, co dzieje się chwili obecnej. Badania pokazują, że nawet pełna świadomość podobieństw i konfrontacja z wiarygodnymi informacjami nie są w stanie zmienić nastawienia i uczuć do tej osoby ${ }^{57}$.

Do tej pory omówione zostały tendencyjności (skróty) poznawcze, które - choć przystosowawcze w wielu sytuacjach komunikacyjnych - w przypadku konfliktu okazują się często mniej adekwatne, a ich działanie może wpływać destrukcyjnie na możliwości porozumienia. Istnieje jednak także pewna grupa błędów poznawczych, które są szczególnie charakterystyczne dla sytuacji konfliktu. Poniżej omówione zostaną najważniejsze z nich: potrzeba uproszczenia konfliktu, widzenie czarno-białe, skłonność do spostrzegania przeciwstawnych sił i dewaluacji reaktywnej.

Dążenie do uproszczenia konfliktu wiąże się z potrzebą uporządkowania i uspójnienia rzeczywistości. Ludzie w swoim postrzeganiu konfliktu skupiają się na ogół na jednym lub dwóch wyrazistych aspektach sytuacji - zazwyczaj tych, które są łatwiej dostępne dla ich aparatu percepcyjnego - i na ich podstawie formułują założenia dotyczące tego, jak się zachować. Zgodnie z opisanymi powyżej zasadami działania procesu percepcji dalsze informacje są przetwarzane zgodnie z przyjętym punktem wyjścia, tzn. dane niezgodne

57 Por. M. McKay, M. Davis, P. Fanning, Sztuka skutecznego porozumiewania się..., dz. cyt., s. 178-179. 
z początkowo sformułowanym przekonaniem mogą być ignorowane, a danie niejednoznaczne będą interpretowane w sposób zgodny z posiadanymi schematami. Konsekwencją upraszczania sytuacji konfliktowych będzie także błędne spostrzeganie relacji przyczynowo-skutkowych, np. dostrzeganie związków, które w rzeczywistości nie istnieją, lub szczególne akcentowanie przyczyn i skutków danego zjawiska ${ }^{58}$. Jeśli strony sporu uproszczą swoje widzenie konfliktu w skrajnie odmienny sposób, to nie tylko utrudni im wzajemne zrozumienie, ale także może zablokować próby budowania wspólnej narracji czy wypracowywania satysfakcjonującego obie strony porozumienia.

Dodatkowym utrudnieniem jest to, że w konfliktach często występuje skrzywienie poznawcze, nazywane widzeniem czarno-białym. Opiera się ono na tym, że intencje i cechy oponenta są postrzegane jako jednoznacznie negatywne, natomiast własne - jako jednoznacznie pozytywne ${ }^{59}$. Osoby będące w konflikcie mają też tendencje do zakładania, że rozdźwięk między nimi jest większy niż w rzeczywistości. Każdą potencjalną korzyść drugiej strony postrzegają jako swoją stratę. Z kolei każda strata drugiej strony - nawet jeśli w istocie nie przynosi im żadnej korzyści - jest zyskiem, już chociażby dlatego, że pomniejsza stan posiadania „przeciwnika”. Zjawisko to nazywane jest skłonnością do spostrzegania przeciwstawnych $\mathrm{si}^{60}$. Naturalną konsekwencją spostrzegania każdej korzyści przeciwnika jako swojej straty jest zjawisko dewaluacji reaktywnej, czyli tendencja strony konfliktu do niższego oceniania oferty - tylko dlatego, że została złożona przez przeciwnika $^{61}$. Rozumowanie, jakie za tym stoi, zakłada, że skoro przeciwnik składa jakąś ofertę, to jest ona dla niego korzystna. A jeśli jest korzystna dla niego, to dla adresata zapewne będzie stratą. Nawet jeśli na pierwszy rzut oka tego nie widać.

\section{Zmniejszanie „przepaści percepcyjnej" między stronami: rola i narzędzia mediatora}

Przyjęcie tezy, że celem mediacji (głównym lub instrumentalnym) jest wzajemne zrozumienie się przez strony, inaczej mówiąc, wypracowanie

58 Por. L. Thompson, J. Nadler, Tendencyjność sądów w rozwiązywaniu konfliktów..., dz cyt., s. 215-216.

59 Por. G. Nordhelle, Mediacja. Sztuka rozwiązywania konfliktów..., dz. cyt., s. 118; E. Aronson, T.D. Wilson, R. M. Akert, Psychologia społeczna. Serce i umyst..., dz. cyt., s. 138.

60 Por. L. Thompson, J. Nadler, Tendencyjność sądów w rozwiązywaniu konfliktów..., dz cyt., s. 217.

61 Cyt za: L. Thompson, J. Nadler, Tendencyjność sq̨dów w rozwiązywaniu konfliktów..., dz cyt., s. 227. 
wspólnego znaczenia, nasuwa pytanie, w jaki sposób mediator może przeciwdziałać powstawaniu przepaści percepcyjnej między stronami i pomagać im w konstruowaniu wspólnej narracji.

Wydaje się, że punktem wyjścia powinno być przyjęcie wspólnego założenia, że mediacja co do zasady nie służy ustalaniu stanu faktycznego, a tym bardziej szukaniu „prawdy”, tylko uwzględnieniu różnych punktów widzenia. Rolą mediatora będzie zatem uświadomienie stronom, że naturalną rzeczą są różne perspektywy widzenia rzeczywistości. W tym aspekcie nieodzowna wydaje się wiedza na temat tego, w jaki sposób rzeczywistość jest konstruowana w toku komunikacji. Opierając się na posiadanej wiedzy, mediator powinien służyć stronom pomocą w zbadaniu i zrozumieniu odrębnych spojrzeń na rzeczywistość, przy założeniu, że każde z nich może być subiektywnie prawdziwe i jako takie jest równouprawnione. W efekcie zaakceptowania przez strony równoważności odmiennych perspektyw możliwa staje się praca nad wypracowaniem wspólnej narracji ${ }^{62}$.

W związku z istnieniem „przepaści percepcyjnej” strony konfliktu mają tendencję do wyolbrzymiania dzielących ich różnic. Aby działać skutecznie, mediator musi dobrze rozumieć perspektywę każdej ze stron, nie wpadając w pułapkę dosłownego przyjmowania wyjściowych stanowisk stron. Oparcie się na prezentowanych na wstępie pozycjach stron może prowadzić do przecenienia skrajności roszczeń i wielkości przepaści dzielącej strony. Tymczasem rolą mediatora jest dotarcie do rzeczywistych perspektyw widzenia problemu i pomoc stronom w dostrzeżeniu, że ich stanowiska nie są tak skrajne, jak może im się wydawać ${ }^{63}$. Działanie takie buduje w stronach wiarę w możliwość porozumienia, co może obniżać ryzyko negatywnego sprzężenia zwrotnego - związanego ze zjawiskiem samospełniającego się proroctwa, bazującego na przekonaniu, że porozumienie nie jest możliwe.

Mediator musi umieć odróżnić tendencyjności poznawcze od manipulacji, definiowanych jako świadome działanie jednostki w celu wywarcia pożądanego wpływu na innego człowieka ${ }^{64}$. Manipulacje w mediacji mogą być skierowane wobec drugiej strony lub wobec mediatora. Skrzywienia poznawcze mają na ogół charakter nieświadomy, tj. dana jednostka może nie zdawać sobie sprawy z tego, że jej własny umysł kreuje obraz niezgodny z intencjami

62 Por. G. Nordhelle, Mediacja. Sztuka rozwiazywania konfliktów..., dz. cyt., s. 114.

63 Por. L. Thompson, J. Nadler, Tendencyjność sądów w rozwiązywaniu konfliktów..., dz cyt., s. 221.

64 Por. G. Nordhelle, Mediacja. Sztuka rozwiązywania konfliktów..., dz. cyt., s. 120. 
nadawcy - często mniej korzystny lub bardziej zagrażający niż w odbiorze zewnętrznego obserwatora. W zależności od tego, czy źródłem zaburzeń komunikacji będą zamierzone manipulacje, czy skrzywienie poznawcze, mediator będzie podejmował interwencje o zupełnie innym charakterze.

Jeśli uda się doprowadzić do sytuacji, w której uczestnicy mediacji zaakceptują to, że ich narracje mogą się różnić - i niekoniecznie oznacza to złą wolę, świadome mijanie się z prawdą czy chęć dokuczenia - kolejnym krokiem będzie neutralizowanie działania tych tendencyjności poznawczych, które destrukcyjnie wpływają na komunikacje. W niektórych sytuacjach pomocne będzie pokazanie stronom mechanizmów działania procesów percepcji i samych tendencyjności poznawczych oraz pomoc we wdrożeniu zmiany we własnym spostrzeganiu. Tego typu praca na komunikacji wymaga jednak przejścia na metapoziom, co w wielu przypadkach może być dla uczestników bardzo trudne. Do koniecznych warunków wyjściowych wykorzystania przez mediatora takiego podejścia należałoby zaliczyć: relatywnie niewysoki poziom konfliktu, relatywnie niewysoki poziom emocji, odpowiednie warunki intelektualne i gotowość mentalną stron. Wydaje się, że znacznie częściej mediator, bazując na posiadanej wiedzy i umiejętności diagnozy, będzie wykorzystywał dostępne narzędzia w celu bezpośredniego wspierania stron w korygowaniu możliwych zaburzeń postrzegania.

Poniżej przedstawione zostaną narzędzia, jakie mogą być przez mediatora wykorzystywane w celu pomocy stronom w budowaniu adekwatnych atrybucji i poprawianiu atrybucji nieadekwatnych. Z uwagi na ograniczoną objętość artykułu nie będzie możliwe przedstawienie uporządkowanego przeglądu mediacyjnych sposobów reagowania na każdą z przedstawionych pułapek poznawczych, postaram się jednak na poziomie bardziej ogólnym naszkicować zarys podstawowych grup narzędzi, którymi dysponuje mediator. Jako że - zgodnie z założeniem - mediator nie pełni roli terapeuty, nie będziemy w tym miejscu analizować narzędzi, które mogłyby być wykorzystane do pracy nad zaburzeniami obrazu samego siebie - również tymi, które mogą wpływać na proces spostrzegania otoczenia i rozumienia wysyłanych przez nie komunikatów. Na marginesie można zauważyć, że poprawa komunikacji zmniejsza ryzyko zachowań mających na celu ochronę samooceny. Zatem w wyniku pracy nad komunikacją i lepszym zrozumieniem mechanizmy bazujące na obrazie samego siebie mają szansę działać bardziej adekwatnie. 
Narzędziem pomocnym w bardziej adekwatnym postrzeganiu przyczyn działań zarówno własnych, jak i drugiej strony - umożliwiającym uniknięcie pułapki tendencyjności działającego i obserwatora, stronniczości oskarżającego czy tendencyjności atrybucji międzygrupowej - może być rozwijanie empatii, w szczególności ćwiczenia obejmujące zmianę perspektyw. Mediator może np. pomóc oskarżającemu w przyjęciu punktu widzenia oskarżanego, tak aby miał on szansę na dostrzeżenie czynników zewnętrznych (lub innych okoliczności łagodzących) wpływających na kwestionowanie zachowanie $^{65}$. Do typowych narzędzi mediatora $\mathrm{z}$ tego obszaru należą pytania do jednej ze stron o to, jak jej zdaniem druga strona mogłaby ocenić daną sytuację czy zachowanie, co może być dla niej ważne i dlaczego, a także prośby o wyobrażenie sobie, jak druga strona może odnieść się do danej propozycji, jakie będzie widziała korzyści i straty z niej płynące. Wszystkie te narzędzia bazują na próbie namówienia rozmówcy do przyjęcia przez chwilę perspektywy widzenia drugiej strony. W tym samym obszarze pozostają też narzędzia opierające się np. na fizycznej zmianie przez strony miejsc przy stole mediacyjnym, która pozwala na „wejście w buty drugiej strony”. Dla rozwinięcia empatii pomocne mogą być także prośby mediatora o parafrazowanie wypowiedzi drugiej strony. Powtarzanie swoimi słowami komunikatu wyrażonego przez „przeciwnika” nie tylko pomaga lepiej uchwycić jego znaczenie, ale także lepiej uświadamia, że mogą istnieć inne sposoby na widzenie rzeczywistości. Bardziej empatyczne spojrzenie na drugą stronę jest także pierwszym krokiem do przeniesienia jej z grupy „oni” do grupy „my”, co ma szanse przełożyć się na zmianę spojrzenia na sytuację, która z poziomu „jestem z nim(i) w konflikcie” zostanie przeformułowana na „mamy problem do rozwiązania”.

Mediator może także uczyć strony lepszej komunikacji - czy to przez modelowanie, czy też poprzez pokazywanie możliwości wykorzystania pewnych narzędzi. Dobrze, aby mediator pokazywał stronom, że choć dla nich samych czynniki kontekstowe stojące za własnymi decyzjami i zachowaniami są oczywiste, z drugiej strony może to wyglądać zupełnie inaczej. Dlatego tak istotne jest, aby mediator pomagał stronom w przedstawianiu rzeczywistego kontekstu realizowanych działań i zachowań. Podejście takie pozwoli minimalizować działanie tendencyjności działającego i obserwatora, które

65 Por. K. G. Allred, Złość i odwet w konflikcie. Znaczenie atrybucji..., dz. cyt., s. 249. 
sprawia, że cudze zachowanie częściej tłumaczymy przyczynami wewnętrznymi, a własne - zewnętrznymi okolicznościami ${ }^{66}$.

Jedną z metod, która pozwala na sprawdzenie poprawności przyjętych atrybucji jest tzw. kontrola spostrzegania ${ }^{67}$. Podejście to nie tylko pozwala sprawdzić, czy przyjęta interpretacja działań drugiej strony jest słuszna, ale zarazem pozwala dostrzec, że istnieje więcej niż jeden kierunek interpretacji danego zachowania. Pozwala uniknąć elementu oceny, który może być zagrażający dla ego drugiej strony, co wtórnie generuje dodatkowe skrzywienie poznawcze i prowadzi do pogorszenia relacji. Użyteczność wykorzystania tej metody potwierdzają badania Charlesa G. Lorda, Marka R. Leppera i Elizabeth Preston, którzy stwierdzili, że uświadomienie sobie przez badanych, że istnieją inne sposoby interpretacji rzeczywistości (po rozpatrzeniu stanowisk przeciwstawnych do tych, które posiadali) prowadziło do zmniejszenia częstości popełnianych przez nich błędów poznawczych ${ }^{68}$.

Kontrola spostrzegania zakłada, że kiedy rozmówca przedstawia swoją interpretację zachowania drugiej strony - np. stwierdzając: „Mąż spóźnił się godzinę po odbiór dzieci, bo w ogóle mu na nich zależy” lub: „Żona spóźniła się godzinę dzieci, bo chciała mi dokuczyć” - prosi się go o sprawdzenie słuszności przyjętej interpretacji. Może to zrobić na trzy sposoby:

- Opisać swoje obserwacje - np. (Matka): „Mąż miał przyjechać o 17.00. Od 16.30 chłopcy dopytywali się, kiedy wreszcie tato będzie. O 17.00 stali z nosami przy oknie. Potem zaczęli się denerwować. Kiedy o 17.30 ciągle go nie było, Antoś najpierw marudził, a potem zaczął kopać w szafki. Wreszcie popchnął brata. Jaś zaczął płakać i mówić, że chce do taty. Antoś powiedział mu, że tata nie przyjedzie, bo go nie lubi”.

- Dać dwie możliwe interpretacje danego zachowania - np. (Matka): „Kiedy mąż spóźniał się godzinę na spotkanie z dziećmi, pierwszą moją myślą było to, że potrzeby dzieci nie są dla męża istotne. Chyba że chodziło o to, że po prostu znowu nie ogarnął rzeczywistości”.

- Poprosić o wyjaśnienie, jaka powinna być właściwa interpretacja - np. (Ojciec): „Wiesz, że mam pociąg, a jednak zjawiasz się godzinę po czasie. Powiedz mi, jak w tej sytuacji mogę rozumieć Twoje spóźnienie.”

66 Por. K. G. Allred, Złość i odwet w konflikcie. Znaczenie atrybucji..., dz. cyt., s. 250.

67 Opis narzędzia: R. B. Adler, L. Rosenfeld, R. Proctor II, Relacje interpersonalne..., dz. cyt., s. 114-115.

68 C. G. Lord, M. R. Lepper, E. Preston, Considering the opposite: A corrective strategy for social judgment, „Journal of Personality and Social Psychology” 47 (6), s. 1231-1243. 
Celem wykorzystania tego narzędzia jest poprawa adekwatności spostrzegania, a zarazem zasygnalizowanie dbałości o drugą stronę. W ten sposób narzędzie to może być wykorzystywane do poprawiania relacji i obniżania poziomu lęku i niepokoju, a co za tym idzie, również wrogości i agresji. Lepsze zrozumienie i mniejsze napięcie mogą z kolei zmniejszyć zagrożenie występowania negatywnego zjawiska samospełniającego się proroctwa, egotyzmu atrybucyjnego czy tendencyjności typowych dla konfliktu: widzenia czarno-białego albo uproszczenia konfliktu.

Sposobem na tendencyjność atrybucji międzygrupowej może być wykorzystanie narzędzia konkretyzacji, czyli takiego wykorzystania języka, aby umiejscowić dane zjawisko w określonym czasie i kontekście. W literaturze wskazuje się, że podkreślanie czasu i warunków, w jakich mają miejsce dane wydarzenia, prowadzi do wykorzystania języka z niższego poziomu abstrakcji. Bazując na przytoczonym powyżej przykładzie spóźnień po odbiór dzieci, zadaniem mediatora byłoby uzyskanie zgody obu stron na omawianie perspektywy dwóch konkretnie osadzonych w czasie i przestrzeni wydarzeń: „Ojciec spóźnił się godzinę z odbiorem synów” czy „Matka spóźniła się godzinę po odbiór synów”, a następnie zastanowienie się, dlaczego miały one miejsce, czy były przejawem jakichś poważniejszych problemów (zaufanie dzieci do rodziców, zaufanie każdego z rodziców do wywiązywania się przez drugiego z ustaleń), jak można takim zdarzeniom zapobiegać.

Pomocne w uzgadnianiu znaczenia mogą być także odpowiednio zadane pytania. W szczególności warto tutaj wyróżnić pytania klasyfikujące, porównujące i demonstrujące. Biorąc za przykład kazus dotyczący spóźnienia, jeśli ojciec mówi: „Matka jest całkowicie nieprzewidywalna”, mediator może zadać pytanie klasyfikujące: „W czym z Twojej perspektywy przejawia ta nieprzewidywalność?”. Mediator może także użyć pytania porównującego: "Jakiego innego słowa mógłbyś użyć, żeby opisać zachowania matki?”. Z kolei w reakcji na stwierdzenie matki: „Synowie nie mogą na ojca liczyć” mediator może zadać pytanie demonstrujące: „Czy możesz opisać, w jaki sposób ta niemożność liczenia na ojca przejawia w waszym codziennym życiu?”. Odpowiednio zadane pytania będą skuteczne nie tylko w przypadku tendencyjności atrybucji międzygrupowej, ale wszędzie tam, gdzie przydatne może być pokazanie pewnego relatywizmu wygłaszanych opinii oraz możliwości spojrzenia na problem $\mathrm{z}$ innej strony. 


\section{Podsumowanie}

Celem opracowania było wykazanie, że percepcja, choć na co dzień niewidoczna, ma istotny wpływ na komunikację i budowanie wzajemnego zrozumienia się jej uczestników. Mechanizmy percepcji w istotny sposób wpływają na przebieg konfliktu, często utrudniając możliwość zrozumienia się przez strony - zgodnie z założonymi przez nie intencjami - a w dalszej perspektywie prowadząc do eskalacji konfliktu. W sytuacji, w której tendencyjności poznawcze utrudniają stronom adekwatny odbiór sytuacji i komunikatów drugiej strony nieocenioną pomocą może służyć mediator - neutralna, bezstronna osoba trzecia, wspierająca komunikację stron w kierunku ich porozumienia. Aby pomoc ta była jak najbardziej skuteczna, mediator powinien dysponować wiedzą obejmującą psychologię procesów poznawczych, umiejętnością adekwatnej diagnozy ich działania oraz narzędziami do poprawiania adekwatności postrzegania stron.

Budowanie zrozumienia przez strony wydaje się pierwszym krokiem na drodze wiodącej do rozwiązania konfliktu i wypracowania porozumienia. Nawet jeśli osiągnięcie wzajemnego zrozumienia nie doprowadzi do porozumienia, a jedynie do stworzenia „protokołu rozbieżności”, to i tak poprawa komunikacji między stronami ma szanse przełożyć się na poprawę - czy chociażby normalizację - relacji, co samo w sobie może zostać uznane za sukces w mediacji.

\section{Bibliografia}

1. Adler R. B., Rosenfeld L. B., Proctor II R. F., Relacje interpersonalne. Proces porozumiewania się, Dom Wydawniczy Rebis, Poznań 2011.

2. Allred K. G., Złość i odwet w konflikcie. Znaczenie atrybucji, w: M. Deutsch, P. T. Coleman, Rozwiązywanie konfliktów. Teoria i praktyka, Wydawnictwo Uniwersytetu Jagiellońskiego, Kraków 2005, s. 236-253.

3. Aronson E., Wilson T.D., Akert R.M., Psychologia społeczna. Serce i umyst, Zysk i S-ka, Poznań 1997.

4. Blumer H., Interakcjonizm symboliczny: perspektywa i metoda, Zakład Wydawniczy NOMOS, Kraków 2007.

5. Griffin E., Postawy komunikacji społecznej, Gdańskie Wydawnictwo Psychologiczne, Gdańsk 2003. 
6. Heider F., The psychology of interpersonal relations, New York: Wiley 1958.

7. Krauss R. M., Morsella E., Konflikt a komunikacja, w: M. Deutsch, P. T. Coleman, Rozwiązywanie konfliktów. Teoria i praktyka, Wydawnictwo Uniwersytetu Jagiellońskiego, Kraków 2005, s. 131-143.

8. Lewicka M., Wojciszke B., Wiedza jednostki i sądy o świecie społecznym, w: Psychologia. Podręcznik akademicki, t. 3, red. J. Strelau, Gdańskie Wydawnictwo Psychologiczne, Gdańsk 2005, s. 27-77.

9. Lord C. G., Lepper M.R., Preston E., Considering the opposite: A corrective strategy for social judgment, "Journal of Personality and Social Psychology” 47 (6), S. 1231-1243.

10. McKay M., Davis M., Fanning P., Sztuka skutecznego porozumiewania się, Gdańskie Wydawnictwo Psychologiczne, Gdańsk 2005.

11. Morreale S. P., Spitzberg B.H., Barge J.K., Komunikacja między ludźmi. Motywacja, wiedza i umiejętności, Wydawnictwo Naukowe PWN, Warszawa 2007.

12. Nordhelle G., Mediacja. Sztuka rozwiązywania konfliktów, FISO Fundacja Inicjatyw Społecznie Odpowiedzialnych, Gdańsk 2010.

13. Tannen D., To nie tak! Jak styl konwersacyjny ksztattuje relacje z innymi, Zysk i S-ka, Poznań 2002.

14. Tannen D., Ty nic nie rozumiesz! Kobieta i mężczyzna w rozmowie, Zysk i S-ka, Poznań 1999.

15. Thompson L., Nadler J., Tendencyjność sądów w rozwiązywaniu konfliktów. Jak ja pokonywać, w: M. Deutsch, P. T. Coleman, Rozwiązywanie konfliktów. Teoria ipraktyka, Wydawnictwo Uniwersytetu Jagiellońskiego, Kraków 2005, s. 213-235.

16. Watzlawick P., Beavin J., Jackson D., Pragmatics of human communication: A study of interactional patterns, pahologis and paradoxes, New York: Norton 1967.

17. Weryk K., Kobieta i mężczyzna - odwieczny dylemat komunikacyjny, w: Paradygmaty i pułapki psychologii komunikowania sie, red. T. Rzepa, Szczecin 2006. 